\title{
Model of operational search prediction of intentional homicide by criminal police
}

\section{Модель оперативно-розшукового прогнозування умисних вбивств підрозділами кримінальної поліції}

\author{
Written by: \\ Yevhen Khyzhniak ${ }^{8}$ \\ https://orcid.org/0000-0001-8263-0353 \\ Andrii Khankevych ${ }^{9}$ \\ https://orcid.org/0000-0002-6897-347X \\ Ihor Nazarenko ${ }^{10}$ \\ https://orcid.org/0000-0003-3544-9863 \\ Oleh Pleskach ${ }^{11}$ \\ https://orcid.org/0000-0002-5003-0342 \\ Oleksandr Tretiak ${ }^{12}$ \\ https://orcid.org/0000-0002-2776-0128
}

\section{Анотація}

Метою статті є визначення моделі оперативнорозшукового прогнозування умисних вбивств підрозділами кримінальної поліції. Предмет дослідження: Предметом дослідження є модель оперативно-розшукового прогнозування умисних вбивств підрозділами кримінальної поліції. Методологія: Методологічною основою статті $\epsilon$ загальні та спеціальні методи та прийоми наукового пізнання, зокрема: нормативно-догматичний метод, гносеологічний метод, монографічний метод, порівняльно-правовий метод, метод моделювання, метод групування, логікоправовий метод, метод узагальнення. Результати дослідження: Надано характеристику методу моделювання при його використанні органами кримінальної поліції. Практичні наслідки: Розглянуто особливості процесу побудови оперативно-розшукової моделі ситуації. Вивчено міжнародний досвід регулювання досліджуваного питання. Цінність / оригінальність: На основі вивчення міжнародного досвіду запропоновано застосування відповідних заходів протидії умисним вбивствам в діяльності Національної поліції України.

\footnotetext{
${ }^{8} \mathrm{Ph} . \mathrm{D}$ in Law, Associate Professor, Associate Professor of the Department of Criminalistics of the National University "Odesa Law Academy", Ukraine.

${ }^{9} \mathrm{Ph} . \mathrm{D}$. in Law, Associate Professor, Professor of the Department of Pre-investigative and Detective activity of Kharkiv National National University of Internal Affairs, Kharkiv, Ukraine.

${ }^{10} \mathrm{Ph}$.D. in Law, Professor of the Department of Pre-investigative and Detective activity of Kharkiv National University of Internal Affairs, Kharkiv, Ukraine.

${ }^{11}$ Ph.D. in Law, First Deputy Head of Poltava Regional Prosecutor's Office, Poltava, Ukraine.

${ }^{12}$ Graduate Student of Kharkiv National National University of Internal Affairs, Kharkiv, Ukraine.
} 
Key words: model, operational search prediction, intentional homicides, National Police, international experience.

\section{Introduction}

Article 3 of the Constitution of Ukraine states that the human being, his or her life and health, honour and dignity, inviolability and security are recognised in Ukraine as the highest social value. To affirm and ensure human rights and freedoms is the main duty of the State.

Accordingly, ensuring safety of citizens, protecting their lives and health from criminal encroachment requires a drastic improvement in the quality of criminal police activities to detect and investigate intentional homicide (Pavlenko, Sevruk, \& Ishchuk, 2015, p. 252). The task of improving the effectiveness of combating intentional homicides determines the importance of sound prediction of crime. Different indicators and characteristics of crime are interrelated and interdependent. Accurate crime forecasting allows developing tactics and methods of combating criminal encroachments, including operational and investigative measures.

At first glance, the detection and investigation of crimes of this category should not pose a problem. Intentional homicides, unfortunately, have been committed and continue to be committed throughout human history. However, new ways of committing and masking murders are emerging with the development of modern technology. Besides, the investigation of such crimes is hampered by the unsatisfactory training of investigators and criminal police officers and the lack of knowledge of the techniques, tactics and organization of detecting and preventing intentional homicides, etc. Given that the law enforcement system is currently being reformed in Ukraine, there is an urgent need to turn to the international experience in combating intentional homicides (Zavorina, 2017).

The urgency of the study is also due to insufficient development of organizational and legal framework for the prevention of intentional homicides. Besides, the increase in the scale of such crimes poses a real threat to the security of the State and society, as it strengthens its position in view of the monopolization of many types of illegal activities, the lack of reliable mechanisms to counter, etc. (Sevruk, 2015, pp. 193-194).
Ключові слова: модель, оперативнорозшукове прогнозування, умисне вбивство, Національна поліція, міжнародний досвід

\section{Methodology}

The methodological basis for the article is general and special methods and techniques of scientific knowledge. Normative and dogmatic method is used in the process of studying domestic legal acts regulating the issue under consideration. Epistemological method is used to interpret the concept of "prediction". Monographic method is applied when considering the views of foreign and Ukrainian on applying this method in policing. Comparative and legal method allows comparing the experience of some States in combating intentional homicide using various methods, including the method of prediction. Modeling method helps to characterize the process of building an operational and investigative model of the situation. The method of grouping is applied for identifying the countries with different intentional homicide rates. Logical and legal method is used for identifying the measures to prevent intentional homicides that should be implemented in the National Police activity. The method of generalization is applied to formulate the relevant conclusions and suggestions.

\section{Literature Review}

Robinson (2018), when studying the role of prediction, argues that this method has been ingrained in all spheres of life, including the activities of criminal police and criminal justice. It involves the use of automated predictions based on statistical samples to predict human behavior. The author considers the problems and challenges of prediction analytics, supporting them with the relevant examples from practice.

Perry, BMcInnis, Price, Smith, \& Hollywood (2013) emphasize that despite the significant number of methods of combating crime that are in the arsenal of the police, the method of prediction is one of the most important. The authors have compiled a guide for police officers, which describes the most effective methods of prediction, the methods that can prove their usefulness in the future, as well as explanations and recommendations for their use.

Moses and Chan (2016) believe that crime prediction is one of the main functions of the police. The author reviews theories and methods 


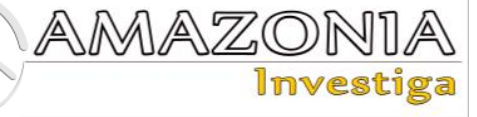

of prediction, and focus on three main issues related to the use of algorithmic prediction: assumption, estimation and accountability.

Ferguson (2017) provides an overview of the development of the institution of police prediction in order to identify the theoretical and practical aspects of this relatively new method.

Some issues of prediction in policing were also considered in the works of domestic scientists. For example, Yosypiv (2009) in his work "Violent crime: determinants and counteraction by law enforcement agencies", examined, in particular, the concept of "identity of the perpetrator of violent crimes", his (her) main features, the most important (in the victimological sense) personal characteristics of victims, which determine their increased victimization. Considerable attention is paid to the factors underlying the contradictions in the socio-economic, socio-psychological, sociocultural, organizational and managerial, family and other spheres of life that affect the formation of criminal behavior.

Criminological and statistical study of intentional homicides, including for mercenary motives, was carried out by (Ihnatov, 2012; 2013). His monograph "Intentional homicide: a criminological and statistical study" (Ihnatov, 2012) is devoted to a comprehensive analysis of the quantitative and qualitative characteristics of all types of intentional homicides, taking into account the specifics of the factors of their latency. The following work of this author "Counteraction to general criminal violent crime in Ukraine" (Ihnatov, 2013) was devoted to theoretical and applied problems of counteraction to violent crime.

\section{Results and Discussion}

According to Art. 2 of the Law of Ukraine "On the National Police" combating crime is one of the main tasks of the Police. Countering crime is a continuous process, within which general and special measures aimed at detecting and solving crimes are carried out simultaneously and in parallel. The effectiveness of combating crime depends on many factors (Sevruk, 2017, p. 289). Accordingly, the organization of activities to combat crime should be carried out in the areas, each of which is conditioned and subordinated to a specific goal, namely:

detection of signs of preparation or commission of crimes; exposing persons who have already committed crimes to bring them to justice;

preventing the involvement of persons in criminal activities;

operational and investigative monitoring (constant current control, critical observation and determination of the state of the object (process) in order to detect changes);

documentation of criminal activity.

All these areas should be considered as interdependent components of crime prevention, which can be clarified and supplemented depending on the negative processes (Hribov, 2014, p. 155).

It should be noted that operational measures include the collection of information about the planned murders, the behavior of specific individuals, the causes of certain crimes that require immediate action. Thus, the characterization of intentional homicides is a system of interdependent generalized data on the most typical features, which can be divided into three complexes, the components of which are closely correlated: the identity of the victim - the identity of the offender; time - place - situation; method of commission - tools - trace picture.

Tymchuk (2015, p. 140) correctly notes in this regard that intentional homicides have minimal latency in any country in the world, so this type of crime most accurately characterizes the degree and scale of social pathology in a country, as well as the level of aggressiveness of society.

Operational units of the National Police should pay attention to the following signs, which in conjunction may indicate the activities of organized criminal groups of general criminal orientation: existence of unsolved robberies, robberies, murders and other serious and especially serious crimes; committing serious crimes over a certain period of time; lack of information on the profiles; lack of confidential information on the activities of organized criminal groups of general criminal orientation; lack of physical evidence; committing crimes in the same way; impertinence in committing crimes (Abdul and Andrusenko, 2017).

Given the above, it should be noted that the operational officers must feel the psychological state, analyze, predict the behavior of the opposite party (offender); it is essential that criminal police officers acquire operational and tactical thinking, the ability to model both the development of a criminal event and the behavior of the object of study and observation. The 
tracking and forensics process requires mastering the techniques of analysis, synthesis of criminal incidents and ability to predict in the preparation of investigative and investigative leads. Operational and tactical knowledge includes the system of organizational and tactical skills in search operations in the relevant operational and investigative situation, the ability to model, plan, use the variety of techniques and methods to create favorable conditions for successful crime fighting; timeliness, completeness, reliability of factual data fixation and use of their results in operative and search cognition (Prypolov, \& Lyzohubenko, 2020, p. 402).

The process of building an operational and investigative model of the situation is a sequence of stages of the process of operational thinking. Operational search actions (measures) are the operational side of the professional thinking of the operational officer. Each element of the information model of the primary situation has a certain operational "dimension", i.e. the quality and quantity of operational and investigative actions that can be applied to it.

These elements and actions in conjunction form the operational dimension of the current tactical situation: the more actions can be applied to the elements of the situation, the higher its operational dimension. When building an operational-information model of a specific situation, the nature of the mental actions of the operational officer, in contrast to those carried out by other specialists (investigators, forensic scientists, physicians), has its own specifics. It lies in considering all the elements of the situation not only and not even as the result of a person's actions, but as a result of reflecting in them his (her) individual characteristics that have operational and investigative significance. In fact, what matters is mainly those elements of action and their results that reveal individual (or group) features of the person, i.e. in one or another way related to these features. Operational and information model should contain these features, which collectively determine the object of search. These links are given concrete expression in terms of the search features of the object of the search, most often in the form of investigative leads (Shvets, 2018, p. 18).

The method of prediction is the forecasting of future events to take preventive measures. It is used in politics, economics, marketing, management, sociology, psychology, pedagogy, law and other fields (Tsilmak, 2017, p.198). The forecasting method can be long-term or shortterm.
At the same time, when identifying the problems that require the joint efforts of law enforcement agencies, priority should be given to the activities to combat banditry, terrorism, human trafficking, intentional homicide, other serious and especially serious criminal offenses, as well as those committed by organized criminal groups and organizations primarily in the area of economics and high technology: illicit trafficking in drugs, weapons and ammunition; criminal and other manifestations of corruption; crime prevention. Selecting issues relevant to coordination it is not just departmental positions that need to be taken into account, but in-depth analysis and accounting law enforcement practices of the country and individual regions (Korniakova, 2017).

In conclusion, it should be noted that it is important not only to conduct a full and highquality inspection, but also to know how to conduct it, what exactly one should do and how to check. That is, one needs to know how to verify reports of intentional homicide and to have a basic understanding of the perpetrators for a complete and high-quality inspection.

Operational search tactics develops techniques and recommendations for the implementation of tactical operational measures and operations, such as detention or neutralization of armed criminals, liquidation of gangs, implementation of comprehensive operational search measures and covert investigation (search) actions.. Modeling as an element of tactics, performing a cognitive role, allows to determine the persons involved in the commission of a crime by the members of an organized group. In particular, the imaginary model of a criminal event is formed in the mind of the operational officer on the basis of the received information. Forecasting is used to develop the correct program of action and management decisions that ensure the best results in the tasks of combating organized crime. As some scientists correctly point out, in this case it is important to use a very productive method of designing behavioural patterns of previously identified persons in similar situations for persons of operational interest (Pohoretskyi, 2012, p. 120).

However, the underlying factor in this process is ambiguity of individual and personal (or just personal) determinants of virtually every criminal offence, the result of actions or the choice of circumstances. This is the main factor that causes the uncertainty of the decisionmaking situation in the disclosure of almost any "non-obvious" crimes. The analysis of the 


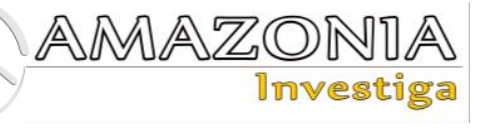

decision-making procedure under such conditions indicates that the initial uncertainty of individual-personal determination is overcome in practice as follows:

- uncertainty in determination of each element (feature) of the situation is overcome by combining, grouping elements, i.e. structuring the original set of features;

- the elements (signs) are combined not by their objective properties (as, for example, in the reconstruction of the mechanism of causing the harmful result that occurred), but by the features and mechanism of their subjective, individual-personal infliction;

- individual personality traits and the mechanism of causing elements of a criminal event are constructed within its specific model in the process of search modeling, which can be called the "plot of the event" as related to a specific (but not yet known) person (Shvets, 2018, p. 17).

Usually, at present, intelligence information is accumulated and used in the activities of units of the Criminal Intelligence Department of the National Police of Ukraine. This information can help and significantly speed up the detection of intentional homicides.

As noted earlier, most people convicted of intentional homicides are characterized by a low level of intelligence and a narrow range of interests. Being from depressed areas, without clearly defined life plans, they tend to spend their time meaninglessly as part of street groups. It is obvious that the needs of such people correspond to their age ideas about the level and way of life. Examining the lifestyles of those who committed intentional homicides, it was found that they are characterized by such distorted needs and interests as the desire to abuse alcohol or drugs, receive sexual services, visit gambling and entertainment facilities, etc. This is evidenced by the results of studying the materials of criminal proceedings. Every fourth person convicted of intentional homicide confirmed that he spent the money from the crime on alcohol and entertainment. Thus, the distortions of needs and the desire to maintain a primitive, parasitic lifestyle have the greatest motivating value for committing intentional homicides (Oberemko, 2017, p. 27).

Persons who have committed murders are generally characterized by low level of spiritual development, the dominance of basic needs. Most of them are sociopaths: anti-social in nature, emotionally stupid, incapable of compassion (Khyzhniak, Khankevych, Shapovalenko, Shkelebei, \& Yatsyk, 2021, p. 215).

Eisner (2015, p. 3) notes in this regard that there are some common patterns associated with homicidal violence. Across the globe the vast majority, between $90-95 \%$, of all perpetrators of homicide are male with little variation between societies. Most homicides committed by females consist of acts against infants and children or entail self-defense in situations of domestic abuse. The majority of victims, $79 \%$ worldwide, are also male but the proportion of male victims varies systematically between societies.

Operational search modeling in the form of constructing an "event plot" can be considered as one of the ways to overcome the uncertainty of its individual and personal (or just personal) determination. The plot is in its essence an integrative, holistic model of the event, but not as a criminal fact, but as a real life situation. Using this type of simulation, police officers make the transition to a different context, different semantic system - real life situations, where a criminal event is considered (and really is) as one of the fragments of the criminal's life. This is a specific context for addressing the problem of solving crime and identifying the person guilty of its commission. The decisions made in this context are not so much analytical as heuristic. The only condition that holds the course of thought in the analytical context is the real signs of the event as part of the evidence base of the investigation. Simulation of this type is a very common technique in the disclosure of complex, non-obvious crimes, which often takes the form of a «brainstorming session», when each participant offers his (her) views on pre-criminal and subsequent events, seeking to find a logic within which more details of the event can fit (Shvets, 2018, pp. 16).

Besides, it is necessary to summarize the international experience of operational and investigative counteraction to intentional homicide and provide proposals for its implementation in the practice of law enforcement agencies of Ukraine. In this context, Zavorina (2017, p. 149) divides all countries of the world into five groups according to the intentional homicide index:

1) States with a very low level of the intentional homicide. These are mainly developed European countries, in particular, Austria, Norway, Spain, Germany, Sweden, the Netherlands, the Czech Republic, 
Switzerland, Ireland, France; some developed countries of Asia (Japan, the Republic of Korea, Singapore); some other Asian countries (Brunei, China, Vietnam). The same group includes: in Africa Tunisia, Morocco, Algeria, Egypt; in Oceania - Australia, New Zealand, Micronesia, Palau; individual Arab states (Bahrain, Kuwait, Saudi Arabia); in North America - Canada;

2) States with a low rate of the intentional homicide: in Europe - Belarus, Bulgaria, Romania, Finland, Latvia, Albania, Montenegro; in Asia - Azerbaijan, Georgia, Israel, Iran, Nepal, India, Thailand; in Africa - Libya, Mauritius, Niger; in Latin America - Chile and Bolivia; in North America - the United States.

3) States with an average level of the intentional homicide. This group includes: in Europe - Moldova, Estonia, Ukraine, Russia; in Asia - Indonesia, the Philippines, Mongolia; in Latin America - Uruguay, Haiti, Bolivia, Cuba, Argentina; in Africa Madagascar, Mali, Senegal, Mozambique;

4) States with a high rate of the intentional homicide. These are mainly African countries (Rwanda, Namibia, Botswana, Sudan) and Latin America (Nicaragua, Paraguay, Mexico, Brazil, Ecuador);

5) States with extremely high rates of the intentional homicide. These are mainly the States of Central (Belize, Guatemala, El Salvador, Honduras) and South America (Colombia, Venezuela), as well as some African countries - South Africa, Lesotho, Swaziland, Zambia.

When countering homicides, it is usually necessary to carry out covert actions in order to quickly and effectively gather information about the preparation and commission of a crime. In particular, Shkolnikov (2016, p. 436) notes that there are three stages of the investigation in the United States: 1) rapid and extremely limited verification of information; 2) preliminary investigation; 3) full investigation. When conducting full investigation, it is allowed to use all covert methods of investigation, such as: the use of confidential cooperation; undercover work and undercover operations; wiretapping; interference in personal communication and electronic correspondence (interference in private communication by electronic means without the knowledge of persons); consensual electronic eavesdropping (with the knowledge and at the request of a person who suspects the occurrence of dangerous consequences for him (her) or the commission of a crime against him (her) and officially applies to law enforcement agencies in this regard); installation of an automatic device that registers telephone numbers, other electronic actions and identifies and automatically establishes the subscriber's number, IP address and other individual features of the primary source of such information without recording the content of the message or conversation; monitoring electronic information systems, the access to which is limited by the owner; surveillance, audio- and video recording of the person. All other methods of secret investigation must be published and made freely available to every U.S. citizen in order to ensure that their rights, freedoms, and legitimate interests are respected. In this regard, it is necessary to agree with the statement of the abovementioned scholar that the general availability of US legislation to regulate the use of confidential cooperation, intelligence work and undercover operations is a positive example for Ukraine.

The final suggestions of analytical prediction in Great Britain can be in the form of:

- $\quad$ strategic analysis, through which long-term plans of law enforcement agencies are developed, strategies and requirements for criminal intelligence are created;

- tactical analysis, on the basis of which shortterm plans of police activities are developed in accordance with the general strategy, and can also be used to supplement the existing requirements for criminal intelligence;

- $\quad$ target profile for a specific person (suspected or victim) or group of persons in accordance with strategic priorities;

- $\quad$ problem profile, which analyzes a specific crime or series of events, etc. (National Centre for Policing Excellence, 2005).

When analyzing foreign experience in the area of crime prevention, Stepanenko proposed to apply the following measures in the activities of the National Police of Ukraine: 1) creation of a Standard Model for Combating Crime at the Regional Level, which will include both general methodological issues and a list of necessary measures classified into sections and subdivisions for certain areas of police prevention; $\quad 2$ ) creation of a coordinating body (council) for crime prevention at the level of regional departments of the National Police. It should be responsible for developing regional prevention policies; planning activities in this area; informing the population on crime prevention, etc.; 3) adoption of short-term regional programs (from one to two) to prevent 


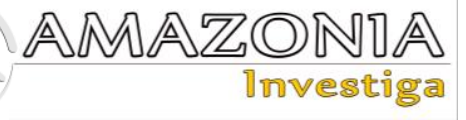

crime. This program should reflect the goals, nature, means, methods and general direction of crime prevention activities at the regional level. The system of measures in this area should also be fixed, the basic levels and directions of activity in the field of crime prevention should be specified (Stepanenko 2016, p.241).

\section{Conclusion}

Summing up, it is worth noting that the model of operational and investigative prediction of intentional homicides by criminal police units is determined by forensically significant features of these crimes, tactical countermeasures, situational factors and the content of selected algorithms for their solution by the National Police of Ukraine. It should be noted that Ukraine inefficiently uses the international experience of law enforcement, especially of developed European countries with very low and low rates of intentional homicides, namely: Austria, Norway, Spain, Germany, Switzerland, Sweden, the Czech Republic, Israel and others. Thus, the prospects for further research in this area are to substantiate effective mechanisms for counteracting intentional homicides by criminal police units, taking into account the international experience of operative-investigative counteraction to intentional homicides with subsequent proposals for its implementation in law enforcement agencies of Ukraine.

\section{References}

Abdul, S. and Andrusenko, S. (2017). Legal and organizational and tactical problems of combating organized crime: textbook. Odessa: ODUVS.

Bennett, L. \& Chan, J. (2016) Algorithmic prediction in policing: assumptions, evaluation, and accountability, Policing and Society, 28(7), pp. 806-

822, DOI: $10.1080 / 10439463.2016 .1253695$

https://www.tandfonline.com/doi/full/10.1080/1 0439463.2016.1253695?scroll=top\&needAcces $\mathrm{s}=$ true

Ferguson, A.G. (2017). Policing Predictive Policing, Washington University Law Review, 94(5), pp. 1109-1189. https://openscholarship.wustl.edu/law_lawrevie w/vol94/iss $5 / 5$

Eisner, M. (2015). How to Reduce Homicide by $50 \%$ in the Next 30 Years. Rio de Janeiro: Igarapé Institute.

Hribov, M. (2014). Means used during covert investigative (search) actions. In: Bulletin of the Ministry of Justice of Ukraine, 9, pp. 152-158.
Ihnatov, AN. (2012). Murder: criminological and statistical research: monograph. Simferopol: KRP Izd-vo Krymuchpedgiz, 2012. 176 p.

Ihnatov, OM (2013). Counteraction to general violent crime in Ukraine: monograph. Kharkiv: Disa Plus, $650 \mathrm{p}$

Khyzhniak, Y., Khankevych, A., Shapovalenko, Y., Shkelebei, V., \& Yatsyk, T. (2021). Features of the prevention of intentional homicide by criminal police units. Amazonia Investiga, 10(38), pp. 212-218.

https://doi.org/10.34069/AI/2021.38.02.21

https://amazoniainvestiga.info/index.php/amazo nia/article/view/1559/1552

Korniakova, T. (2017). Prosecutor's office and bodies of non-departmental control: supervision and interaction. (PhD Dissertation). Odesa National Law Academy, Ukraine.

Law No. 580-VIII, 2015. Official Gazette of the Verkhovna Rada of Ukraine, Kyiv, Ukraine, July 02, 2015.

Law No. 254k/96-VR, 1996. Official Gazette of the Verkhovna Rada of Ukraine, Kyiv, Ukraine, June 28, 1996.

National Centre for Policing Excellence (2005). Guidance on the National Intelligence Model. UK: ACPO Centrex. https://whereismyd ata.files.wordpress.com/2009/01/nationalintelligence-model-20051.pdf

Oberemko, Yu. (2017). "Socio and psychological factors of intentional homicides committed for personal gain". In: Scientific Bulletin of Kherson State University, Series: Law, Issue 1(4), pp. 26-30.

Pavlenko, S., Sevruk, V., \& Ishchuk, D. (2015). Investigation of murders related to the disappearance of a person: problematic issues and areas for improvement. Available online. In: http://elar.naiau.kiev.ua/bit stream/123456789/8163/1/\%d0\%9f\%d0\%a0\%d $0 \% 90 \% \mathrm{~d} 0 \% 92 \% \mathrm{~d} 0 \% 9 \mathrm{e} \% \mathrm{~d} 0 \% 92 \% \mathrm{~d} 0 \% 86 \% 20$ $\%$ d0\%a0\%d0\%95\%d0\%a4\%d0\%9e\%d0\%a0\%d $0 \% 9 c \% d 0 \% 98 \% 20 \% \mathrm{~d} 0 \% \mathrm{a} 7 \% 201 \_\mathrm{p} 255$ -

257.pdf. Consultation date: 09/03/2021.

Perry, W.L., McInnis, B., Price, C.C., Smith, S.C., \& Hollywood, J.S. (2013). Predictive Policing: The Role of Crime Forecasting in Law Enforcement Operations. USA: Rand Corporation. https://ww w.rand.org/content/dam/rand/pubs/research_rep orts/RR200/RR233/RAND_RR233.pdf

Pohoretskyi, M. (2012). Correlation of forensic and operative-search tactics in the context of the new Criminal Procedural Code if Ukraine. In the collection: Reforming the system of criminal justice in Ukraine: criminal law, criminal procedure and forensic problems of the International scientific and practical conference on the occasion of the 10th anniversary of the 
Irpin Financial Law Academy and the 80th anniversary of the birth of the famous scientist criminologist of modern times Professor Bakhin. Irpin: Irpin Financial and Law Academy. 252-255 p.

Prypolov, I. and Lyzohubenko, E. (2020). Tactics of counteraction to crime by the divisions of the criminal police of Ukraine: professional readiness of the operational officer. Legal scientific electronic journal, 3, pp. 400-403. http://www.lsej.org.ua/3_2020/99.pdf

Robinson, D. (2018). The Challenges of Prediction: Lessons from Criminal Justice. 14 I/S: A Journal of Law and Policy for the Information Society, 151, pp. 152-186. https://core.ac.uk/download/pdf/185249983.pdf. Sevruk, V. (2015). Measures to counteract transnational drug trafficking committed by the representatives of certain ethnic groups. Legal Journal of the National Academy of Internal Affairs, 2, pp. 193-205.

Sevruk, V. (2017). Counteraction to crimes committed by organized groups and criminal organizations that are formed on an ethnic basis by the National Police of Ukraine. Entrepreneurship, economy and law, 2(252), pp. 288-293.

Shkolnikov, V. (2016). Application of covert methods of investigation in criminal proceedings: foreign experience. In: Journal of the Kyiv University of Law of the National Academy of Sciences of Ukraine, 4, pp. 434-437. Shvets, D. (November 30, 2018). Operational search modeling in crime detection. In the collection: Modern problems of legal, economic and social development of the State of the International scientific and practical conference. Kharkiv: $\quad$ KhNUVS. P. Kharkiv. P.16-18. http://dspace.univd.edu.ua/xmlui/bitstream/hand le/123456789/3870/Operatyvno_rozshukove $\% 2$ 0modeliuvannia_Shvetc_2018.pdf?sequence $=4$ \&isAllowed $=\mathrm{y}$

Stepanenko, K. (March 17, 2016). Prevention of crime at the regional level by the police: foreign experience and its implementation in Ukraine // In the collection: World experience of police training and its implementation in Ukraine of the International scientific and practical conference. Dnipropetrovsk: Lira LTD. 239-241 p.

Tsilmak, O. (2017). Modern methods of pre-trial investigation of criminal offenses: a textbook Odessa: Phoenix.

Tymchuk, O. (May 22, 2015). Some criminological aspects of the state of premeditated murders in the world. In the collection: Actual problems of criminal law and criminology in the light of reforming criminal justice of the International scientific and practical conference. Kharkiv: KhNUVS. P. 140-141.

Yosypiv, AA (2009) Violent crime: determinants and counteraction by internal affairs bodies (dis. ... Cand. jurid. Science) State University of Internal Affairs Affairs, Lviv. 290 p.

Zavorina, O. (2017). International experience of countering units of the national police with murders committed by minors. Forum Prava, 5, pp. 148-156.

DOI: http://doi.org/10.5281/zenodo.1194880 htt ps://zenodo.org/record/1194880\#.YIkKC9UzaU 1 